\title{
腐食疲労に関する最近の諸問題
}

\author{
駒 井 謙 治 郎* \\ *京都大学工学部

\section{Current Problems on Corrosion Fatigue} \\ Kenjiro Komai* \\ *Faculty of Engineering, Kyoto University
}

\begin{abstract}
Current problems on the environmental effects on fatigue of metals have been reviewed. Contained items are as follows: atmospheric corrosion fatigue, exo-electron emission and corrosion fatigue, corrosion fatigue of a material sensitive to stress corrosion cracking, influence of stress cycle frequency, influence of stress wave forms, long life corrosion fatigue strength under service conditions and $\Delta K_{\mathrm{TH}}$, and electric protection against corrosion fatigue.
\end{abstract}

\section{1. まえがき}

機械，構造物の破壊はその洼とんぞが疲労によるもの であるが，その疲労破壊に対して環境が大きい影響をも つ。繰返し応力を受ける前に前腐食を受けていても，一 般にはその害は大きくない。腐食性環境中で同時に繰返 し応力を受けるとき，疲労強度の低下が著しく，これを 腐食疲労といら。腐食疲労は応力腐食割れ (SCC) と異 なり，材料一環境の組合わせをとわず，純金属でも起こ ることが知られている。明らかな腐食性環境のみなら ず，大気中に拈いてはその雲囲気成分，油中に执いては 含まれる吸着性物質が疲労強度に大きい影響を与える。 一般の機械，構造物の破壞には意外に腐食疲労に上るも のが多く，また気がつかない場合むあるので，使用環境 に充分注意する必要がある。最近になって，高強度材料 の開発と利用が進むにつれて，機械，構造物の破壊に占 める腐食疲労の重要性が，とくに強調されてきている。 さらに, その取扱いも最近は, 破壊力学的に処理される ことが多くなっている。

腐食疲労に括いては，通常の疲労に環境側の因子が加 わるために，その影響因子は極めて多様となる。さら 飞，低繰返し速度になると腐食疲労による被害に，SCC による被害が重畳して現われることがあり，未解決の問 題が数多く残されている。

ここでは腐食疲労について，とくに最近注目を集めて いる事柄に重点を置いて，解説を試みたい。

* 于606 京都市左京区吉田本町 (Sakyo-ku, Kyoto 606, Japan)

\section{2. ガス環境中の腐食疲労}

大気中には酸素, 水蒸気, その他種々の污染物質が存 在する。水蒸気が材料表面に凝縮するときは，湿食とし て作用するので, 腐食疲労の害が明らかであり, 污染物質 を水分に含むとき腐食疲労を促進するであるう。また， このような腐食作用は及洼さなくとも，大気中の酸素， 水蒸気が材料表面，とくにき裂先端の新生面に吸着する ことによって，疲労挙動が大きく変化することがある。 材料のき裂進展を論じるにあたって，大気雲囲気の影響 を無視することは，非常に危険であろう。

真空中に执いては，疲労強度は大気中より大きくなる が，その程度は真空度に左右される。真空圧と疲労寿命 の間には，図 $1^{1)}$ のような関係が多く得られている。表

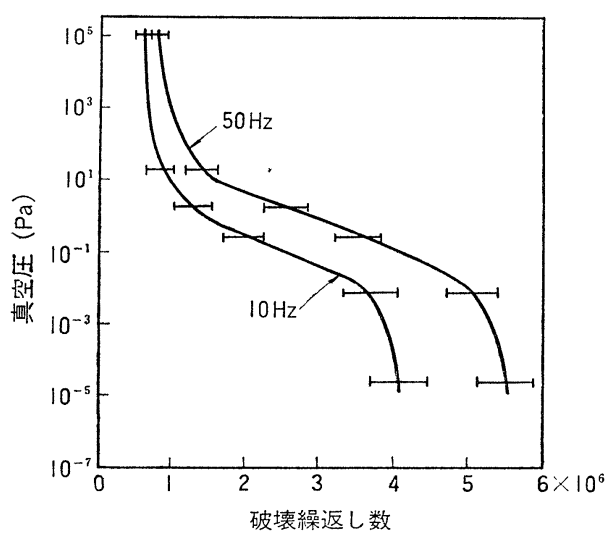

図 1 疲労寿命と真空度の関係 ${ }^{1)}$ (1100-H $14 \mathrm{Al}$ 合金) 
面に微細なき裂を生ごたとき，き裂の開いている引張り の半サイクルの時閣と，き裂壁面にガス分子が吸着する に要する時間の関係が真空度によるため, $10^{0} \sim 10^{-3} \mathrm{~Pa}$ で寿命に大きい変化を生じる。しかし，さらに真空度が 高いとき，とくに低応力・長寿命域で寿命が再び減少す る傾向がある2)。

$5056 \mathrm{Al}$ 合金の種々の真空度における，き裂進展速度 を図 $2^{2)}$ に示す。き裂速度は $d l l d n=C n l^{*}\left(l^{*}\right.$ : 切欠き 深さ十き裂長さ) で与えられるので，綎軸に真空圧，横 軸に係数 $C n$ をとって示している。き裂進展速度が真空

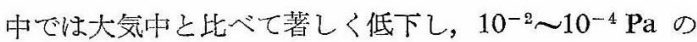
範团でほぼ一定となるのは，図 1 と同様であるが，さら に高真空になると，低応力域で逆にき㤠進展速度が増加 する。10-7 Pa の超高真空になると，高真空脱気の害作 用はさらに明瞭になり，応力值によらずき裂速度が增加 する。このとき，き裂先端に生成する塑性域寸法は，真 空圧が低下するほど増加し，とくに $10^{-7} \mathrm{~Pa}$ の超高真空 中に拊る塑性変形がきわめて著しいことが注目される $\left(\right.$ 図 $3^{2)}$ 。

需囲気ガスのうち疲労強度に影響を与える分子として は，主として酸素と水蒸気が考光られるが，その影響は 材料によって異なる。炭素鋼の疲労き裂の進展には酸素

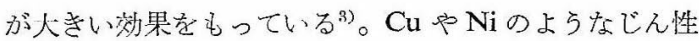
材屯同様な僸问がある。

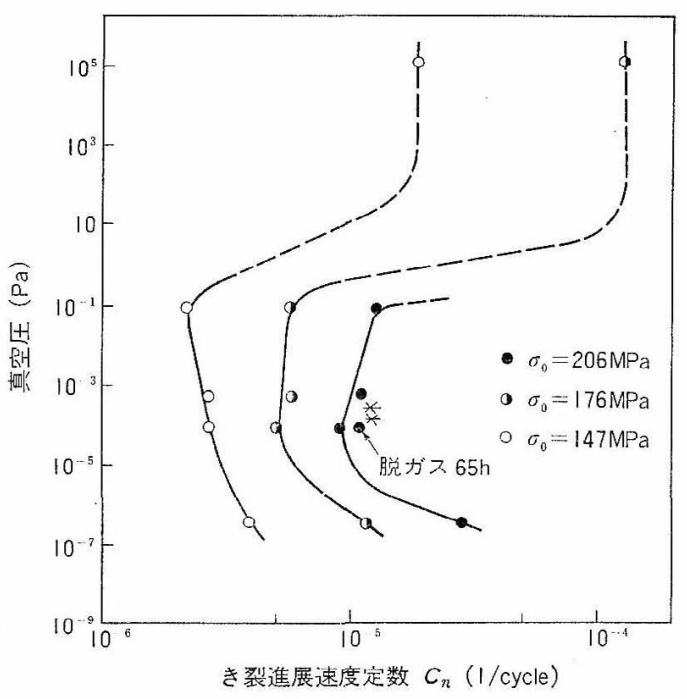

図 2 き裂進展速度定数と真空圧の関係 ${ }^{2}$ (5056 Al 合金)

一方， SCC に敏感な高力 $\mathrm{Al}$ 合金や高力鋼では水蒸 気の害が非常に大きい。図 44) は高力 $2024 \mathrm{~T} 3 \mathrm{Al}$ 合金 の疲労き裂の進展が，水蒸気に大きく影響される例を示 す。雲围気中の水蒸気分圧とき裂進展速度の関係の一例 を図 $5^{5)}$ に示すように，き裂進展に影響を与えるのに必 要な臨界の水蒸気圧が存在するが，この臨界水蒸気圧は

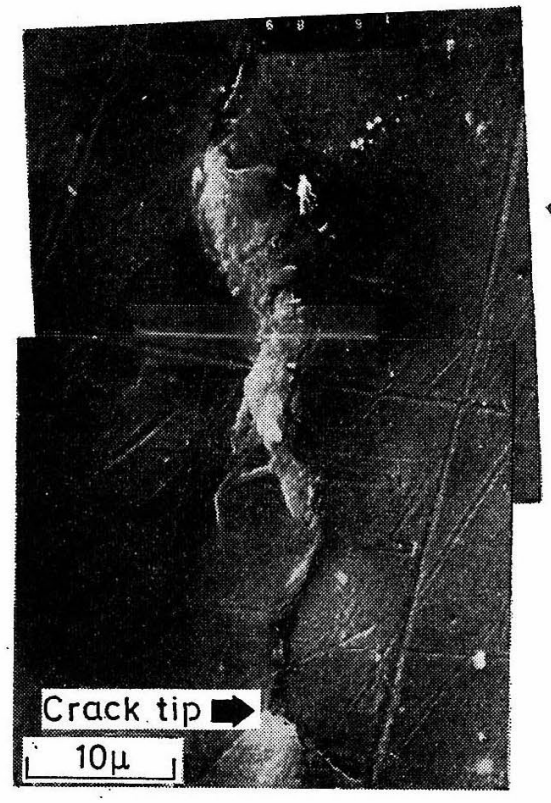

(a) 空 中

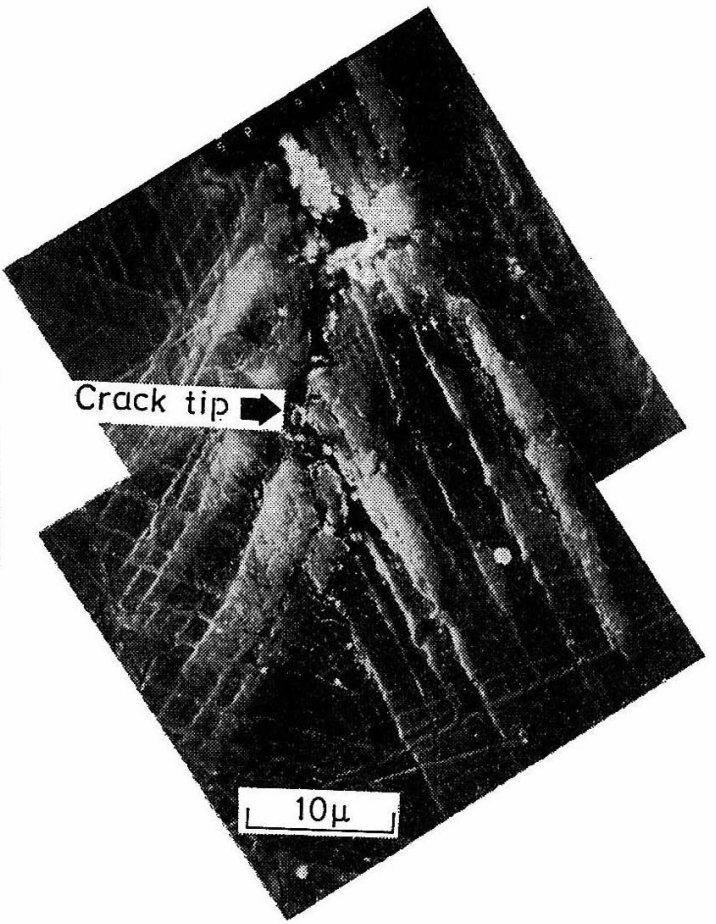

(b) $10^{-7} \mathrm{~Pa}$ 中

図 3 き裂先端に生じた塑性域2) 


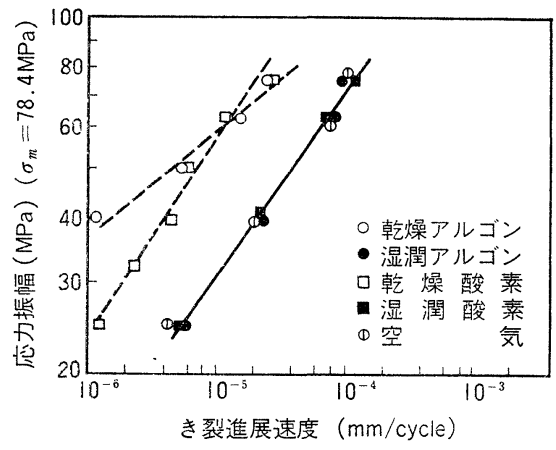

図 4 き裂進展速度に及ぼすガス分子の影響4) (2024 T3 Al 合金)

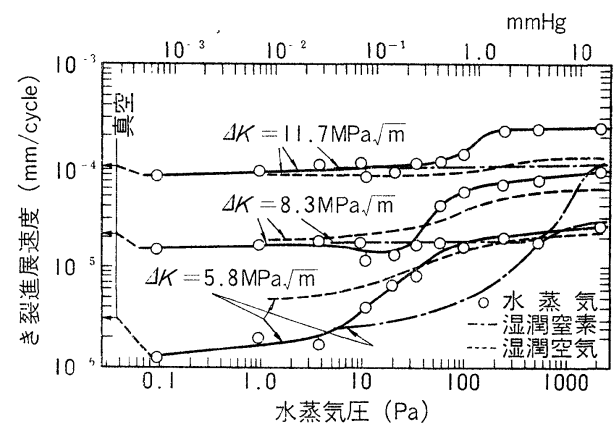

図 5 水蒸気圧とき裂進展速度の関係 ${ }^{5)}$ (DTD5070A Al-Cu-Mg 合金, $f=100 \mathrm{~Hz}$ )

繰返し速度とき裂進展速度の積に近似的に比例し ${ }^{5)}$, 応 力比 $R=K_{\min } / K_{\max }$ の増加とともに低下する ${ }^{6)}$ 。き裂速 度は一般に酸素分圧に依存しないがき)，き裂進展速度が 小さい $\left(<10^{-5} \mathrm{~mm} /\right.$ cycle $)$ 範囲では，図 4 にも見られ るように，酸素によっても若干き裂進展が加速されるよ らである。

湿度 (R.H.) の影響の他の一例を図 $6^{7)}$ に示す。ここ で興味あるのは, ワセリンで被覆して環境を隔離したと き, 疲労寿命は環境の湿度にかかわらずほぼ一定で，低 湿度のとさはかえって弱いことであり，油が相当に水分 を含有するためであると考えられている。高力 $\mathrm{Al}$ 合金 が雲囲気の湿度に大きく影響される例はほかにも多い が，高湿度ではほぼ一定の寿命になる。これはき裂内に 水蒸気が毛管凝縮して, 腐食疲労の現象になるためであ る。

水蒸気の影響は高力鋼に捈いても著しい。AISI 4340 鋼による実験結果が数多く見られるが，き裂進展には酸 素の影響は少なく，湿度に大さく影響される。しかも， 純度 $99.9995 \%$ のアルゴンと, 純度 $99.998 \%$ のアルゴ ソ中ですでにさ裂速度に差が見られ8), 極めて微量 $\left(10^{-1} \sim 10^{-2} \mathrm{~Pa}\right)$ の水分が影響を及ぼす。塗膜による防 食を行うにあたって, きわめて高い塗膜性能が要求され

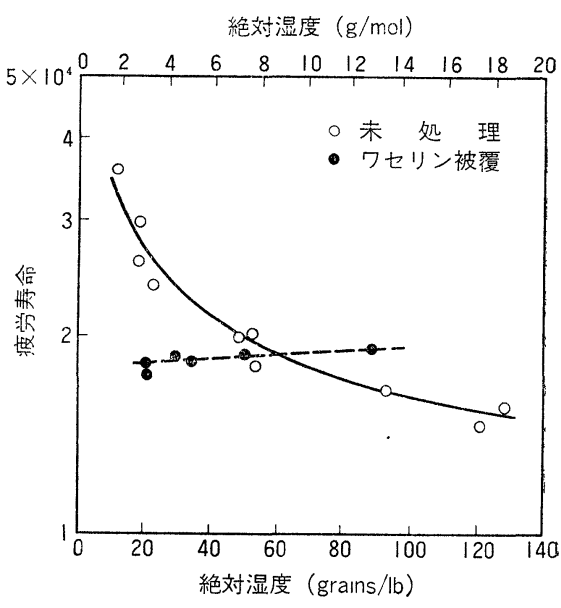

図 6 疲労寿命に及ぼす湿度の影響(7) (7075 T6 Al 合金)

るゆえんである。 RH〜 60\%でき裂速度は最大值をと り，これより高い RH では水中と同じ值をとる。この ような水蒸気の影響は，水蒸気がき裂先端よりのエキソ エレクトロンと反応して水素を発生し，これが金属格子 内に侵入して水素脆化をきたすためであろら (後述)。

\section{3. エキソエレクトロンと腐食疲労}

金属新生面は見かけ上，外部よりエネルギーを受ける ことなしに電子（エキソェレクトロン）を放射し，これ は自然電子放射 (クラマ効果 ${ }^{9}$ ) ) と呼ばれている。電子 放射の機構に関しては不明の点が多いが，金属表面より の電子放射挙動は，金属表面の欠陥密度やひずみの大き さ，酸化の程度などに支配され，また，疲労による表面 状態の変化と密接な相関々係にあることが明らかになり つつある10,11)。

また，エキソエレクトロンは周囲環境と化学反応をお こすことが知られて和り，たとえば, Grunberg ${ }^{12)}$ は水 中で種々の金属を切削し, 周囲の水と酸素から生成した 過酸化水素をヨウ素法で定量した。得られた結果を表 $1^{12)}$ に示すように, $\mathrm{Zn}, \mathrm{Al}, \mathrm{Ni}$ は $1 \mathrm{~h}$ の切削によって約

表 11 時間切削後検出した過酸化水素の量 ${ }^{12)}$

\begin{tabular}{|c|c|c|c|c|c|c|}
\hline \multirow[b]{2}{*}{ 金 } & \multirow{2}{*}{$\begin{array}{l}\text { 切削 } \\
\text { 回数 }\end{array}$} & \multicolumn{2}{|c|}{ 大きさ } & \multirow{2}{*}{ 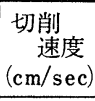 } & \multirow{2}{*}{$\begin{array}{l}\text { 水の } \\
\text { 温度 } \\
(\mathrm{C})\end{array}$} & \multirow{2}{*}{$\begin{array}{l}\mathrm{H}_{2} \mathrm{O}_{2} \\
(\mathrm{mg})\end{array}$} \\
\hline & & $\begin{array}{l}\text { 長 己 } \\
(\mathrm{cm})\end{array}$ & $\begin{array}{c}\text { 幅 } \\
(\mathrm{cm})\end{array}$ & & & \\
\hline 鉛 & 450 & 8.5 & 1.3 & 2.12 & 19 & 2.75 \\
\hline アルミニウム & 450 & 8.5 & 1.2 & 2.12 & 20 & 2.38 \\
\hline マグネシウム & 450 & 7.7 & 1.1 & 1.92 & 19 & 2.66 \\
\hline ニッケル & 655 & 7.7 & 1.4 & 2.80 & 30 & 2.47 \\
\hline 銅 & 450 & 7.7 & 0.9 & 1.88 & 20 & $0 \sim 0.34$ \\
\hline 鉄 & 450 & 7.7 & 1.2 & 1.92 & 20 & $5.62 *$ \\
\hline
\end{tabular}

* $18.4 \mathrm{mg}$ の第 2 鉄イオンに相当する過酸化水素 
$3 \mathrm{mg}$ の $\mathrm{H}_{2} \mathrm{O}_{2}$ を生成するが, $\mathrm{Cu}$ では $\mathrm{H}_{2} \mathrm{O}_{2}$ を洷とん ぞ生成せず， $\mathrm{Fe}$ に扔いては相当量の第 2 鉄イオンを作 る。 $\mathrm{Cu}$ において医とんぞ $\mathrm{H}_{2} \mathrm{O}_{2}$ を生成しないのは, $\mathrm{Cu}$ が表面反応によって $\mathrm{H}_{2} \mathrm{O}_{2}$ を分解するためである。 清浄な金属表面がそれに接した写真フィルムを感光さ せる性質は，ラッセル効果として知られるが，これはエ キソェレクトロンが直接感光剂作用するのではなく， $\mathrm{H}_{2} \mathrm{O}_{2}$ を生成しこれが感光作用を呈することによると説 明されている。Grosskreutz ${ }^{13)}$ は $99.99 \%$ の多結晶 $\mathrm{Al}$ を，一定のひずみ振幅 $( \pm 0.2 \%)$ で $5 \times 10^{4}$ 回（推定寿 命のほぼ $10 \%$ ）引張り圧縮の 繰返しを与えた後，オー トラジオグラフをとり，疲労によって生じたすべり帯 が，きわめて明瞭にラッセ儿効果として現われたことを 報告している。

Bennet $^{14)}$ む $\mathrm{Al}$ 合金と炭素鋼平滑材に薄くて気密性 のあるテープを密着させて疲労試験を行うと, 疲労過程 の後半で金属表面からのガス放出が観察されることを報 告し, このガスは空中の水分による $\mathrm{H}_{2}$ と思われると述 ベている。しかし，このガスはエキソエレクトロンによ り生成した $\mathrm{H}_{2} \mathrm{O}_{2}$ と考学る方が自然であるら。

電子增倍管を用いた計数機構により, 疲労に伴らエキ

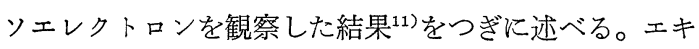
ソェレクトロンは空気中では直ちに減衰するので，その 測定は $1 \sim 2 \times 10^{-3} \mathrm{~Pa}$ の真空中で行われているが，応 力繰返しに伴らエキソェレクトロンの変化の一例を図 $7^{11)}$ に示す。計数のベースラインを $10 \mathrm{mV}$ にとった場 合, 繰返し応力を受ける前の電解研磨面よりのエキソエ レクトロンは, 毎秒数カウント以下であるのに対し, 疲 労試験開始とともにカウント数は激増し, ある繰返し数 で最高值をとって後は漸減し，ほぼ一定值に落ちつく。 疲労試験の途中で試験機を停止させて後の, エキソェ

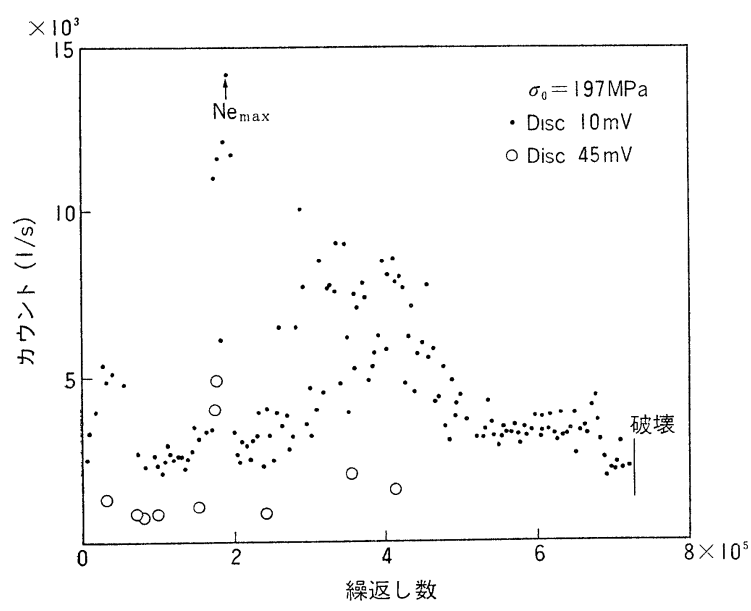

図 7 エキソェレクトロン数の変化 ${ }^{11}$

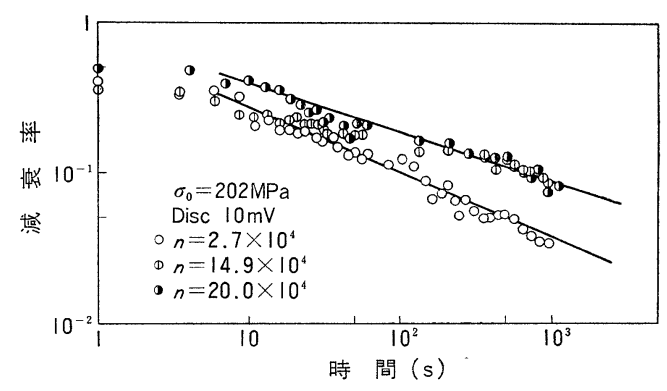

図 8 エキソエレクトロンの減衰 ${ }^{11)}$

レクトロンの減衰を図 $8^{111}$ に示す。縦軸は停止直前のエ キソェレクトロン数を 1 として，それに対する割合を， また横軸は試験機停止後の経過時間を, 両対数尺でとっ ている。エキソェレクトロンの減衰はとくに初期にきわ めて速く, 四からもわかるように, その半減期は $1 \mathrm{~s}$ 以 下である。エキソェレクトロンの減衰がきわめて速いこ とは, 繰返し応力により活性化した表面がきわめて短時 間のうちに，初期の活性度を失うことを示しており，こ れは，腐食疲労被害に対する腐食作用之繰返し応力の同 時作用の重要性と関連している。また, 疲労初期とエキ ソェレクトロン数最大となる繰返し数 (図 7 の $N e_{\max }$ ) 以後とでは, 減衰は疲労初期に拈いてとくに著しいこ と, 経過時間が 10 20 s を超えてからは, 両対数尺上 で直線的な減衰挙動を示し, 疲労のごく初期（図8で $\left.n=2.7 \times 10^{4}\right)$ をのぞくと，一定の勾配 $(-0.33)$ となる。 エキソェレクトロンの経時変化に対しては, 真空度や 䨌囲気の 残留ガス成分が影響することが 知られている が，図 8 と同様な条件でのワイヤブラシによる $\mathrm{Al}$ 摩擦 面からの摩擦後の減衰の勾配一 $1^{15)}$ とくらべると, 図 8 の勾配 $(-0.33)$ は相当に小さい。すなわち, 疲労被害を 受けた金属表面は, 機械加工面に比べると, エキソェレ クトロンの減衰が小さいことは注目に值する。

疲労過程中の種々の繰返し数に批子るエキソェレクト ロンのパルス波高分布を図 911) に示す。縦軸はベースラ イン $10 \mathrm{mV}$ 以上の放射電子数を $100 \%$ としたときの, 各ウィンドウ幅内に入るパルス数の百分率をとり, 横軸 はウィンドウ幅を $20 \mathrm{mV}$ にとったパルス波高をとって いる。図よりもわかるように，パルス波高分布に対して は疲労被害の程度は影響せず, 応力繰返し数にかかわら ず，ほぼ一定の波高分布となる。

機械加工面からのエキソエレクトロンの有する平均の 運動エネルギーは約 $0.2 \sim 2 \mathrm{eV}^{16)}$ といわれて拈り, $1 \mathrm{eV}$ は $96 \mathrm{KJ} / \mathrm{mol}$ に相当するから, 通常の化学反応をひき おこすに必要な活性化ェネルギーと同程度になる。した がって, 疲労強度に及ぼす環境効果を論ずるにあたって も, 繰返し応力による金属表面からのエキソエレクトロ 


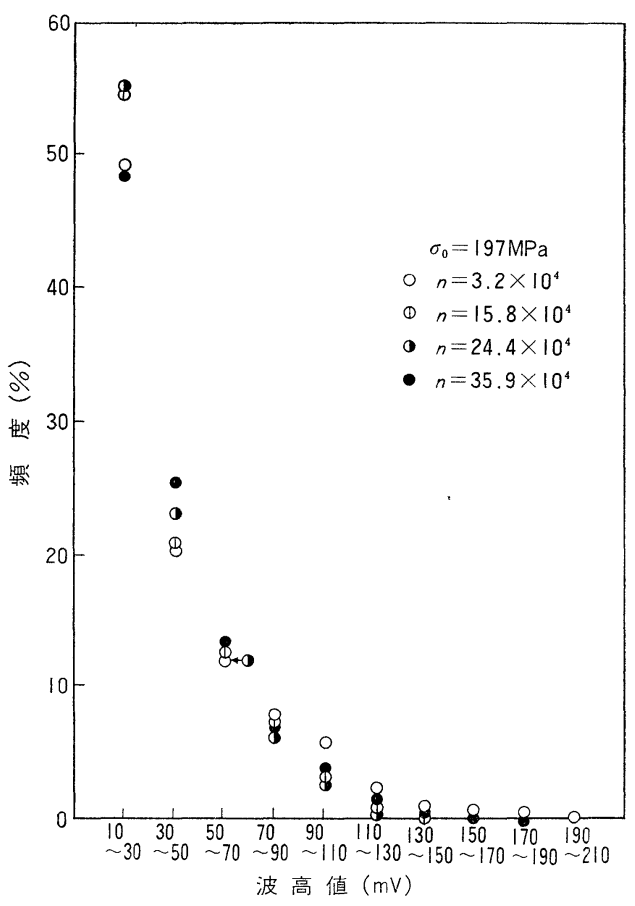

図 9 パルス波高分布 ${ }^{11)}$

ンの影響を無視できないであろう。前章で述べたよう に, $\mathrm{Al}$ 合金, 高力鋼に対しては大気中の水蒸気による 害作用が顕著で, その原因は水蒸気による水素脆化に求 められることが多いが，その機構は不明とされてきた。 H-OH の結合エネルギーは $501.2 \mathrm{~kJ} / \mathrm{mol}, \mathrm{O}-\mathrm{H}$ の結合 エネルギーは $423 \mathrm{~kJ} / \mathrm{mol}$ であり, 上述のエキソェレク トロンの有する平均のエネルギーと比べるとかなり大き いが，疲労過程に淤るエキソェレクトロンの波高分布 の大きな幅を考孚ると，エキソェレクトロンのらち高エ ネルギーを有するものは，H-OH 結合ないしは O-H 結 合の解離に必要なエネルギーを有するものと考兄られ る。

すなわち，高力 $\mathrm{Al}$ 合金，高力鋼の疲労強度に，水蒸 気が影響を及ぼすメカニズムの一つとして, 繰返し応力 に上る金属表面よりのエキソェレクトロンが，雾囲気中 に存在する水蒸気を解離し, 原子状の水素が金属内に吸 蔵されて, 水素脆化をむたらすという過程は十分に考兄 られる。これに関連して，Broom ら ${ }^{17)}$ は高力 $\mathrm{Al}$ 合金 の疲労寿命に対しては, きわめて微量の水蒸気が大きく 影響し, 液体窒素トラップで乾燥した $\mathrm{H}_{2}, \mathrm{O}_{2}$ などは, 逆に大気中より疲労寿命を増加させたことを報告してい る。エキソェレクトロンに対しては $\mathrm{O}_{2}$ の存在が不可欠 であること ${ }^{15)}$, 電子放射量は水蒸気分圧の増加とともに 激增すること郚を考穴合わせると，Broom らによる結 果むエキソェレクトロンで説明できるようである。
このようにェキソェレクトロンは，疲労に及ぼす環境 効果を論ずる上からも，無視できない現象であり，環境 効果の機構解明の重要な一手段となりらる。さらに, 電 子顕微鏡をはじめとする表面観察手段と異なり，エキン エレクトロンは容易に計数, 波高解析ができるので, 定 量的な表面性状の評価が可能であるといら大きな特長を 有する。観察手段としても, 今後の大きな発展が期待さ れる技術の一つであるう。

\section{4. 応力腐食割れ (水素脆化を含む) 条件下の腐食疲労} 応力腐食割れ (SCC) は腐食疲労とは別の現象である が，腐食疲労強度に強く影響する。水溶液中に掓る SCC ばかりでなく，空中，油中などに掠いても，含有 するわずかな水分が水素脆化をひきおこして, 疲労強度 に大さな影響を与えることもある。

水素脆化を起こしやすい高強度 4340 鋼の疲労き裂の 発生と進展に及洼す環境効果 ${ }^{199}$ について述べる。供試材 は $850^{\circ} \mathrm{C}$ より水焼入れされたのち, $600^{\circ} \mathrm{C}, 400^{\circ} \mathrm{C}, 250^{\circ} \mathrm{C}$ で空冷焼もぞしをうけて扤り，その抗張力はおの打の $1030 \mathrm{MPa}, 1570 \mathrm{MPa}, 1820 \mathrm{MPa}$ である。600 $\mathrm{C}$ および $250^{\circ} \mathrm{C}$ 焼もどし材の公称応力振幅 $\sigma_{a}=294 \mathrm{MPa}$ に挍け る, 切欠き材 (切欠底半径 0.4 , 応力集中率 2.4) の回 転曲げき裂進展曲線を図 $\left.10^{19}\right)(f=23.3 \mathrm{~Hz})$, 図 $11^{19)}(f$

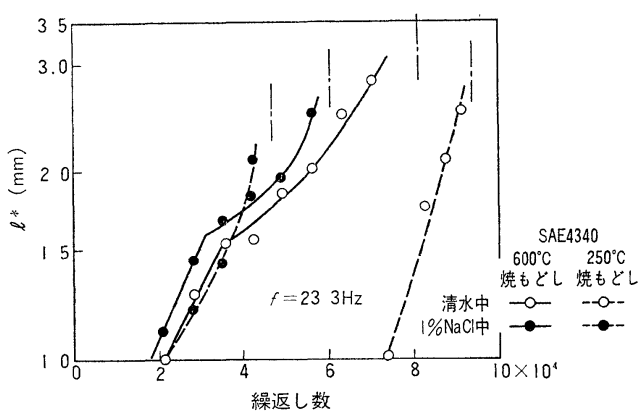

図 $10 \mathrm{HE}$ と腐食疲労の共存下のき裂進展曲線 ${ }^{19)}$ (4030 鋼)

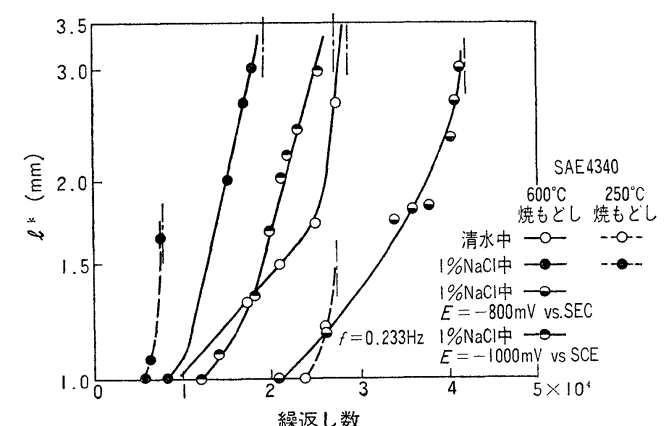

図 $11 \mathrm{HE}$ と腐食疲労の共存下のき裂進展曲線 ${ }^{19)}$ (4340 鋼) 


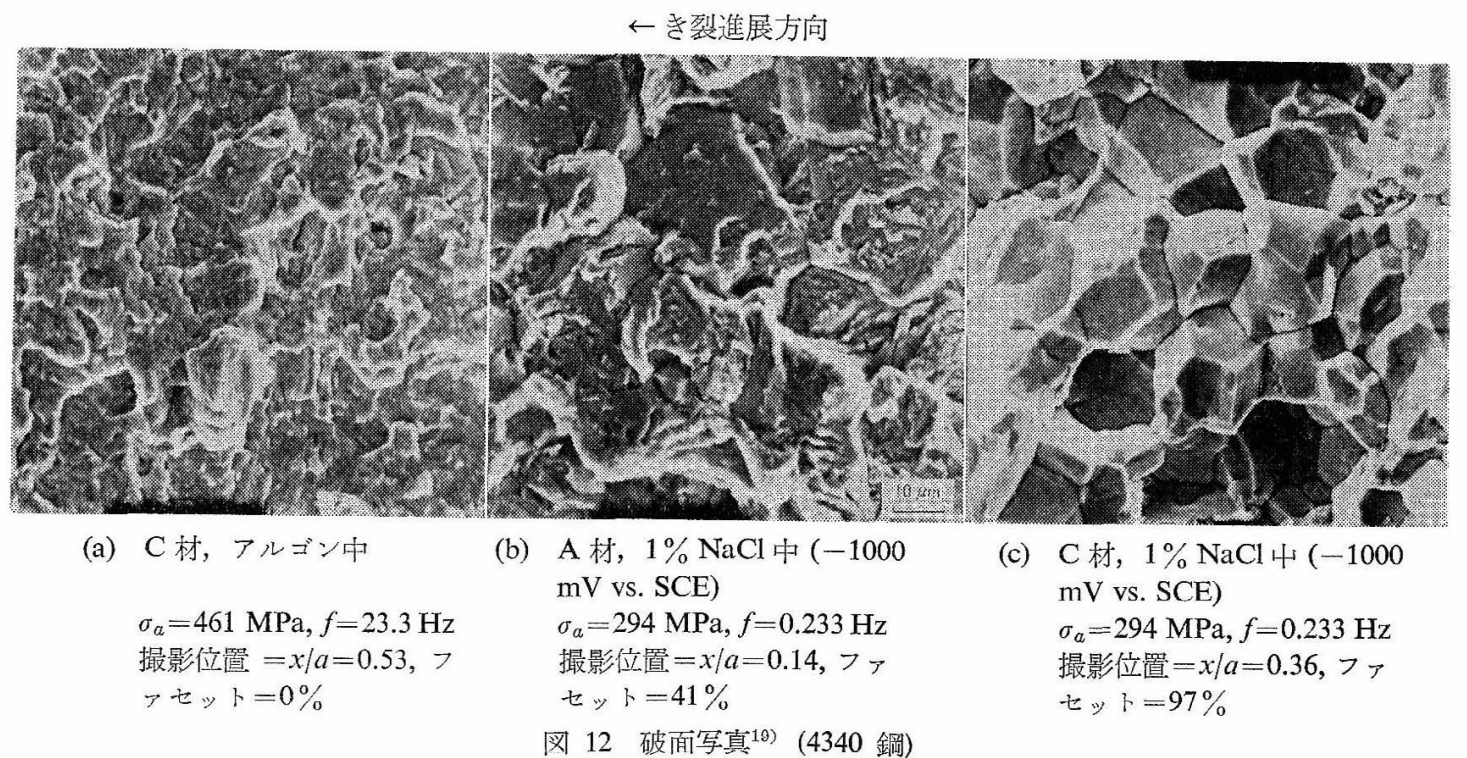

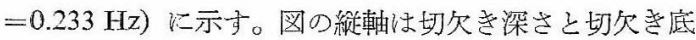
からのき裂深さの和 $\left(l^{*}\right)$ の対数であり，図中の垂直方向 の1点鎖線は破壊までの絽返し数を示している。

$f=23.3 \mathrm{~Hz}$ ではき裂発生に及泟す水素脆化の影響は 少なく, 水素脆化により敏感な $250^{\circ} \mathrm{C}$ 焼もどし材のき 㤠発生末での繰返し数 $(\mathrm{Ni})$ は，水中にて $600^{\circ} \mathrm{C}$ 㭠もど し材より著しく大きくなるが，噟食作用の強い $1 \% \mathrm{NaCl}$ 中自然腐食下では，両材とも Ni 飞差がない。一方， $250^{\circ} \mathrm{C}$ 焼もどし材のき裂進展速度は, 環境を問わず $600^{\circ} \mathrm{C}$ 簿もどし材より增加し，かつ，後者では腐食生成 物によるくさび奻果 ${ }^{200}$ が現れて，あるき裂深さよりき裂 速度が減少するが，前者ではき裂進展が水素脆化によ。 て加速されるため，くさび効果は見られない。き裂進展 に対する水素脆化の害作用は，高繰返し速度域でも，䓵 もどし温度の低い高 $\sigma_{B}$ 材で㵔しく, 後述の破面観察 るこれを裏付ける。

低繰返し速度 $(f=0.233 \mathrm{~Hz})$ になると，き裂発生に対 てむ水素脆化の影響が著しくなり， $600^{\circ} \mathrm{C}, 250^{\circ} \mathrm{C}$ 暁电 どし材ともに，Ni が $f=23.3 \mathrm{~Hz}$ に比べると減少し，と く $250^{\circ} \mathrm{C}$ 䇢むどし材の $\mathrm{Ni}$ の減少が著しい。また， $600^{\circ} \mathrm{C}$ 焼もどし材においても, カソード電位 $E=-1000$ $\mathrm{mV}$ vs. SCE 下に招いて， $E=-800 \mathrm{mV}$ vs. SCE下より き裂進展速度が大きくなる。水中，1\% $\mathrm{NaCl}$ 中自然腐

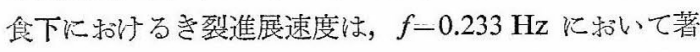
しく增加しているが，この原因は， $600^{\circ} \mathrm{C}$ 焼もどし村で は，〈さび勃果の消減とき裂先端の腐食溶解によるのに 対し， $250^{\circ} \mathrm{C}$ 岏もぞし材では，破面に占める粒界，粒内 ファセット率の藸しい堌加（図 13）より水素脆化によ って和り，両材料で原因が異なっている。

図 $12^{19)}$ に走査型電顕による破面写真の一例を示す。
図 12 (a) は $250^{\circ} \mathrm{C}$ 暁もどし材の精製アルゴン $\left(\mathrm{H}_{2} \mathrm{O}<\right.$ $40 \mathrm{ppm}$ ) 中に甜けるるので, き裂進展方向に直角にほぼ 等間隔の, 疲労ストライエーション状の 2 次割れが全面 にわたって見られる。(b), (c) 怯抒のおの $f=0.233 \mathrm{~Hz}$

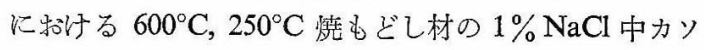
一ド電位 $E=-1000 \mathrm{mV}$ (vs. SCE) 下の破面で, 水素脆 化により生じたと思われる粒内一き開と粒界割れモード が現れ，とくに，(c) の $250^{\circ} \mathrm{C}$ 痑もどし材に捻いては, 破面のほとんどが粒界割れによるファセットで占められ るようになる。破面に占める粒界, 粒内ファセット部の 破面率と, 切欠き底加らの検查面中央までの距離 $x$ を, 最終不安定破壊時のき裂深さ $a$ で除した值 $(x / a)$ との関

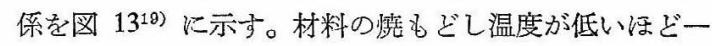
(a), 繰返し速度が低い汪ぞ一(b), カソード印加電位が負 になるほど (図省略)，ファセット率は増加しここれら はいずれも，材料内への水素溶解量の增加が，ファセッ 卜出現率の增加とよく対応して，水素脆化をひきおるこ ていることを示す。

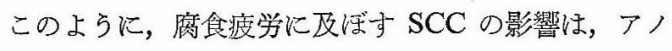
一ド溶解型 SCC のみならず水素脆化に括いても，き裂
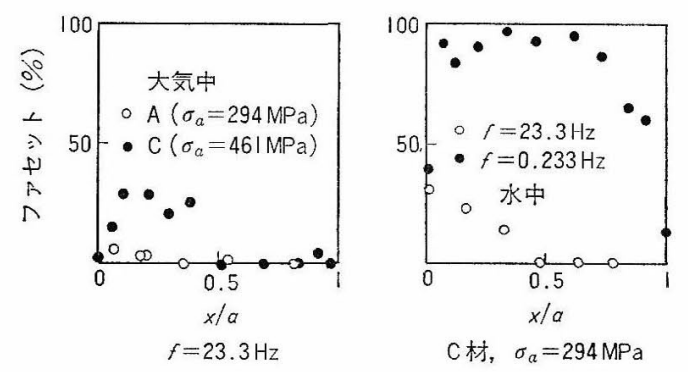

図 13 粒界・粒内ファセット百分率 ${ }^{19)}$ (4340 銅) 
発生の促進として現われるが，とくにき裂進展速度の加 速が顕著である。この場合, 破壊力学の手法を用いるの が適当であり, き裂進展速度と応力拡大係数の関係が詳 しく研究されている。これについてはのちに詳しく述べ る。

\section{5. 繰返し速度効果}

腐食疲労においては, 繰返し速度の影響が大きいこと はよく知られているが，低繰返し速度域ではさらに， SCC 感受性によって速度効果が相違し, かっ, 速度効 果とともに応力波形効果が重要となる。また，腐食疲労 では平滑材でも寿命の大半がき裂進展期で占められるの で，裂進展速度と繰返し速度の関係を明らかにする必 要がある。近年，破壊力学パラメータを用いた，腐食疲 労き裂進展に及淁す繰返し速度効果济関する研究がいく つか見られるようになったが，そのほとんどは高強度脆 性材に限られ，使用の機会の最も多い勒性材について

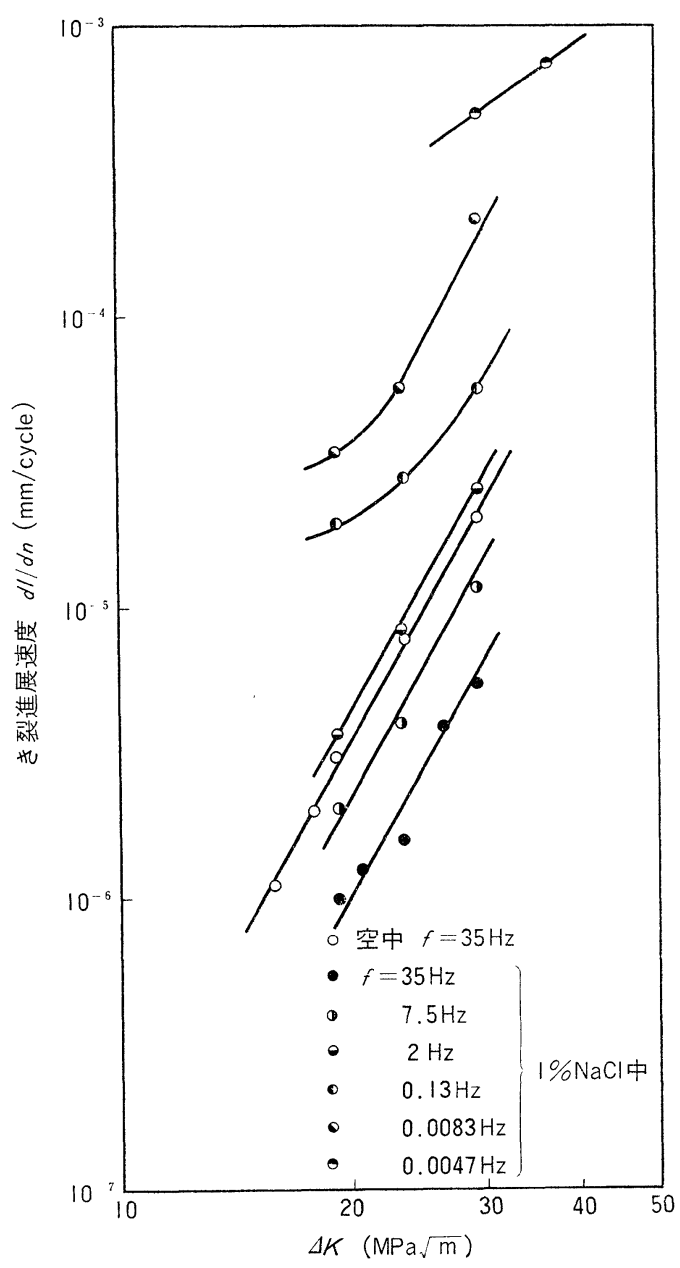

図 14 腐食疲労き裂進展速度と $\Delta K$ の関係 ${ }^{21)}$ $\left(0.16 \% \mathrm{C}\right.$ 孷素鋼, $\left.\mathrm{R}=K_{\min } / K_{\max }=-1\right)$
は，ほとんど報告を見ない。 $0.16 \% \mathrm{C}$ 炭素鋼の $1 \% \mathrm{NaCl}$ 中に抢ける, 回転曲げ疲労き裂進展速度と繰返し速度の 関係を図 $14^{21)}$ に示す。き裂速度はうず電流法によっ $\tau$, 非破壊的に連続して測定されて招り, 応力比 $R=$ $K_{\min } / K_{\max }=-1$ である。高強度鋼 (12Ni-5Cr-3Mo 綱) の $K_{\mathrm{ISCC}}$ より小さい $\Delta K$ に対する結果 $(f=0.1 \sim 10 \mathrm{~Hz})^{22)}$ と同椂に, 各繰返し速度に和ける進展速度曲線は互いに 平行で，低速汪ぞき裂速度が增加する。しかし，腐食溶 解によるさ裂進展が支配的となり， $d l / d t$ (対時間き裂進 展速度）が一定となりはじめる $f \leqq 0.13 \mathrm{~Hz}$ では，速度 曲線の平行性は失われ，とくに腐食性環境の影響を強く 受ける低 $\Delta K$ 域で， $d l / d n$ の加速が著しくなる。同様の 傾向は $13 \mathrm{Cr}-8 \mathrm{Ni}-2 \mathrm{Mo} \mathrm{PH}$ ステンレス鋼の塩水中き裂 進展 $(f=0.083 \mathrm{~Hz})^{23)}$ 飞和いて子観察されて和り，き裂 進展の機構が異なるとき， $d l / d n-\Delta K$ 曲線の勾配もまた 異なることを示す。

一方，材料が SCC を起こすとさは，異なった速度効 果が現れる。 $3.5 \% \mathrm{NaCl}$ 中の 4340 鋼 $\left(\sigma_{0.2}=1300 \mathrm{MPa}\right.$, $\left.K_{\mathrm{ISCC}}=248 \mathrm{MPa} \sqrt{\mathrm{m}}\right)$ 飞おいては， $K_{\mathrm{ISCC}}$ の上下でき裂 進展に及ぼす速度効果が著しく相違する。図 $15^{24)}$ に対 時間き裂速度 $d a l d t$ と繰返し速度 $f$ の関係を示すよう に, $K_{\mathrm{ISCc}}$ より大きい $K_{\max }=\Delta K=65.2 \mathrm{MPa} \sqrt{\mathrm{m}}$ では $f=0.005 \mathrm{~Hz}$ 以下で $d a / d t$ が一定になり，速度効果をるつ のに対し， $K_{\mathrm{ISCO}}$ より小さい $K_{\max }=\Delta K=21.7 \mathrm{MPa} \sqrt{\mathrm{m}}$ では $f=0.01 \mathrm{~Hz}$ 以下で $45^{\circ}$ の傾きとなり, 対繰返し数 き裂速度 $d l / d n$ が一定，すなわち，速度効果を示さな い。 $K_{\mathrm{ISCC}}$ より大きな $\Delta K$ 領域では速度効果が見られる が， $K_{\mathrm{ISCC}}$ より小さい $\Delta K$ 領域では速度効果が見られな いといら結果は， $3.5 \% \mathrm{NaCl}$ 中の $\mathrm{Ti}$ 合金到と执いても

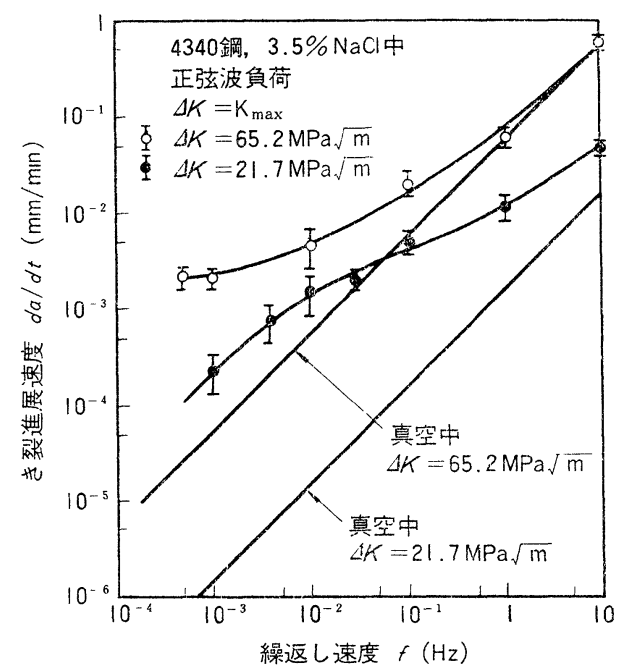

図 15 裂進展速度と繰返し速度の関係 ${ }^{24)}$ (4340 鋼, $3.5 \% \mathrm{NaCl}$ 中) 
観察されて扔り， $K>K_{\mathrm{ISOC}}$ では低速ほどき裂速度が大 きくなるが， $K<K_{\mathrm{ISCC}}$ では速度効果は見られない。し かし，これらの結果は此較的短時間の試験で得られたも のであり, 対象とするき裂進展速度も比較的大きい範囲 にある。実用上必要とされるのは，さらに低い $\Delta K$ にお けるき裂進展速度であって，その場合には腐食と力学的 応力の相乗作用, たと兄ばき裂先端の腐食溶解が大きな 問題となろう。

\section{6. 応力波形効果}

台形状応力波形で， 1 応力サイクルを無応力保持時 間, 一定 (引張り) 応力保持時間, 応力変動時間にわけ て，抢の扮のの時間の腐食疲労被害に及ぼす影響の概略 を整理すると，表 2 のらである。表の中で，十とある のは腐食疲労被害を軽減する防護効果，一とあるのは腐 食疲学被害を促進する損傷効果を意味し，腐食疲労のみ が起こる場合 ( $<K_{\mathrm{ISCO}}$ 条件) と, SCC が共存する場合 （> $K_{\mathrm{ISCO}}$ 条件）にわけて示してある。 SCC 条件のいか んによらず, 腐食疲労被害の本質は応力変動にある ${ }^{26,27) 。 ~}$ また，〈 $K_{\mathrm{ISCO}}$ 条件下では，無応力（一定応力）保持は 腐食疲労被害を軽減するが27)，> $K_{\mathrm{ISCC}}$ 条件下では引張 応力保持の害作用孔無視できない。

表 2 損傷効果 $(-)$ と防護効果 $(+)$

\begin{tabular}{|c|c|c|}
\hline & $<\mathrm{K}_{\mathrm{Iscc}}$ & $>\mathrm{K}_{\mathrm{Iscc}}$ \\
\hline 無 応 力 保 持 & ++ & + \\
\hline 一定応力 (引張り)保持 & + & - \\
\hline 応力 変 動 & -- & -- \\
\hline
\end{tabular}

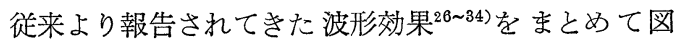
16 に示す。腐食疲労被害に及ぼす損傷効果の拈执よそ の程度を, 図中の - の数で表わし, この場合も $K_{\mathrm{ISCO}}$ 条件と $>K_{\text {ISco }}$ 条件にわけて示している。

$<K_{\mathrm{ISOO}}$ 条件に执いては，三角波，正弦波は常に応力 が変動しているために強度が最小になり，かつ両者の損 傷効果に差がない。方形波による損傷効果は，三角波， 正弦波と比べると小さく，とくに正パルス波の損傷効果 が小さい。応力変動による被害が，無応力時間の防護効 果によって大きく軽減されたためである (表 2)。また， 正のこ歯状波は，三角波，正弦波とほぼ等しい損傷効果 を示すが，負のこ歯状波で応力変動の害が見られないこ とが注目される。すなわち, 応力上昇時の応力変動が顕 著な害をもたらすようである28,30)。波形 G は負パルス 波の最大応力保持時間に，小振幅の応力が重睤した場合 でこのよらな応力波形は実際の機械, 構造物でしばし ば見受けられるものである。< $K_{\mathrm{ISCO}}$ 条件下の重畳小波

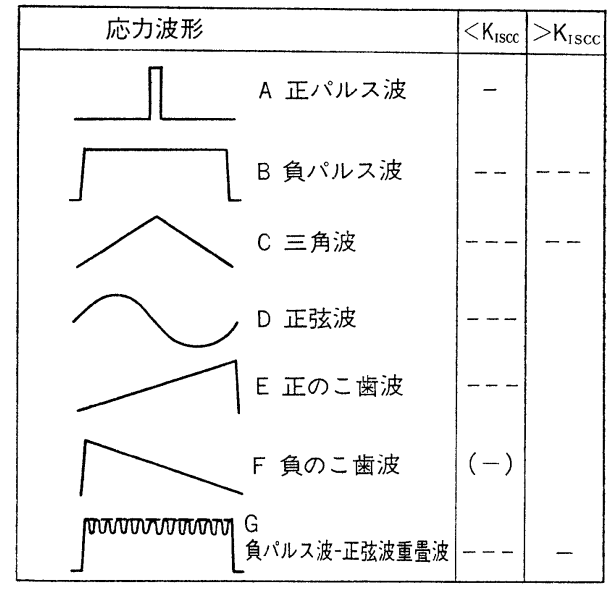

図 16 波形効果のまとめ

効果については，入門講座（腐食疲労）で詳しく述べら れているが，小波を重畳することによって，腐食疲労 き裂の発生が大きく促進され，腐食疲労寿命が激減す $3^{31}$ 。

一方, $>K_{\mathrm{ISCO}}$ 条件においては, 応力変動時間の損傷 効果よりも, 最大応力保持時間の損傷効果のほうが大き

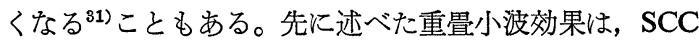
を扰こす場合大きく異なってくる。図 $17^{33)}$ に $1 \% \mathrm{NaCl}$ 中に接ける， SCC 鋭敏化処理をした $\mathrm{Al}-\mathrm{Zn}-\mathrm{Mg}$ 合金の 重畳 2 次波の応力拡大俰数幅 $(\Delta k)$ 之台形状 1 次波に対 するき裂進展速度 $(d l / d N)$ の関係を示す。 $K_{\mathrm{ISCC}} \cong 21.7$ $\operatorname{MPa} \sqrt{\mathrm{m}}$ であり, 大 $K_{\max }$ 領域では $\Delta k$ の重冨とともに $d l l d N$ は著しく減小するが，これは $\Delta k$ によってき裂先 端の腐食溶解が加速され，き裂が鈍化していることによ

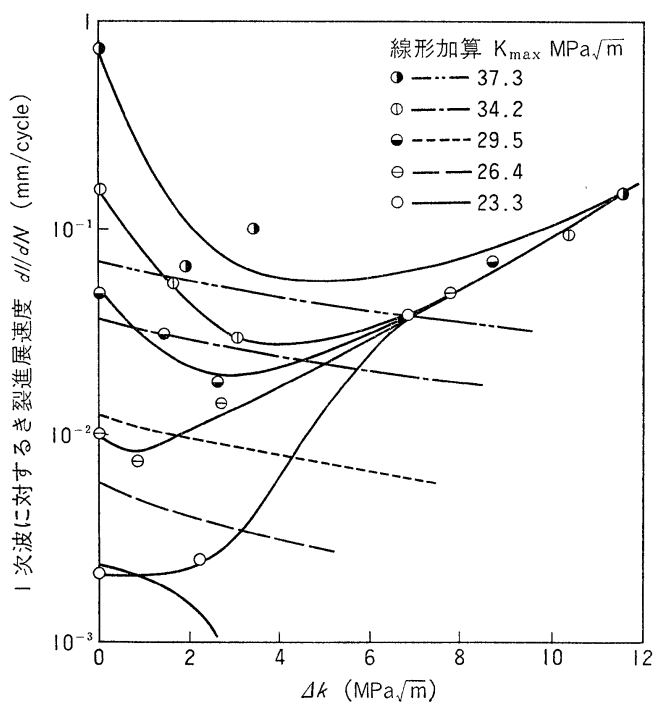

図 17 き裂進展速度に及ぼす重畳小波の影響33) ( $\mathrm{ZK}-41 \mathrm{Al}$ 合金, $1 \% \mathrm{NaCl}$ 中) 
る。さらに $\Delta k$ が大きくなると逆に $d l / d N$ は增加し $K_{\max }$ によらず $\Delta k$ による腐食疲学被害が $d l l d N$ を決定するよ らになる。一方 $K_{\max } \cong K_{\mathrm{ISCC}}$ では $\Delta k$ による $d l / d N$ の減 少は見られず， $\Delta k<1.5 \sim 1.9 \mathrm{MPa} \sqrt{ } \mathrm{m}$ で $d l l d N$ は一定 となる。园中の細線は Wei と Landes による線形加算 則 ${ }^{34)}$ 亿よる計算結果を示すが， $\Delta k=0$ ，すなわち台形状 1 次波のみが作用するときの $d l d d N$ の計算値と实験値の 差がきわめて著しい。これは 1 次波の大応力変動による $\mathrm{SCC}$ 被害の増加を考慮に入れていないためである。

\section{7. 長時間実働環境腐食疲労強度と $\Delta K_{\mathrm{CF}}$}

実用部材の應食疲学汇基因すると思われる事故は，一 般にきわめて長時間の稼動後に生じていることが多いの で, 設計データとしては低応力で長寿命域の, 実働環境 下の強度が必要となるが，現在洼とえど資料が得られて いない。 $N=10^{9}$ に及ら゙䩒鋼 (S15C) の $1 \% \mathrm{NaCl}$ 中䋀食 疲労の $S-N$ 曲線を図 $18^{35}$ ) 飞示す。空中耐久限 $\sigma_{w}=196$ $\mathrm{MPa}$ の材料が，f=52 Hz の回転曲げを受けることによ って, $N=10^{7} \sim 10^{8}$ で腐食疲労強度 $\sigma_{w c}=50 \mathrm{MPa}$ にな

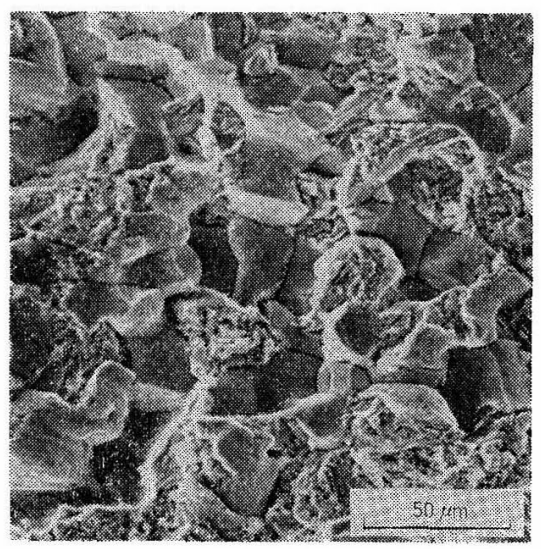

(a) 粒界粒内混合面 $\left(\sigma_{a}=118 \mathrm{MPa}\right)$

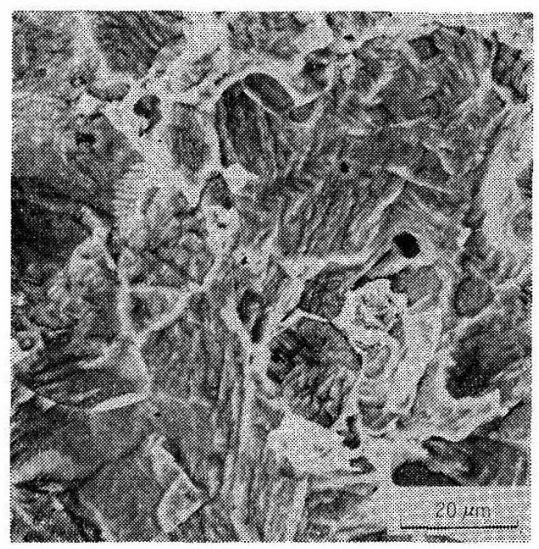

(c) 腐食谁展面 $\left(\sigma_{a}=49 \mathrm{MPa}\right)$

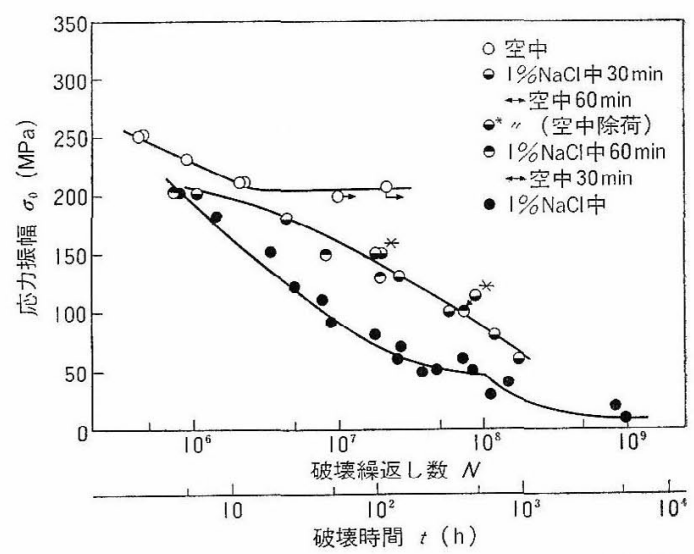

図 18 長寿命域と乾湿繰返しに拈子る $\sigma-N$ 曲線 ${ }^{35)}$ (S15C)

るが，さらに長時間の繰返し応力を負荷することによ り, $\sigma_{w c}=20 \mathrm{MPa}$ 以下の強度にまで低下寸る。

このように腐食瘦労強度の低下は長時間域で珘しい が，とくに $S-t$ 曲線が $t=500 \sim 1000 \mathrm{~h}$ 近傍でいったん その下降傾问が鈍化したあと，再び急激に下降しはじめ

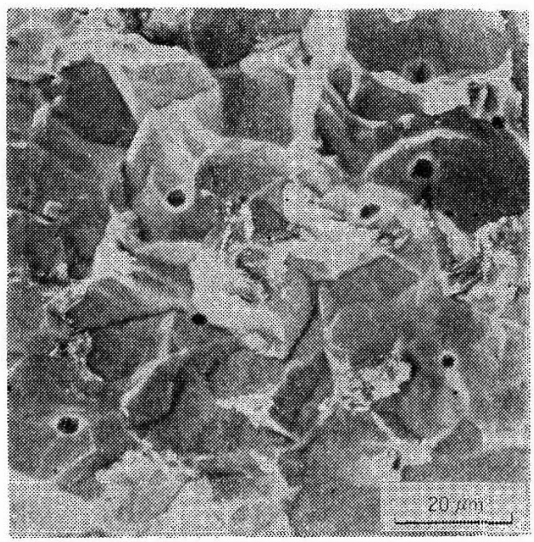

(b) 确食谁展面 $\left(\sigma_{a}=9.8 \mathrm{MPa}\right)$

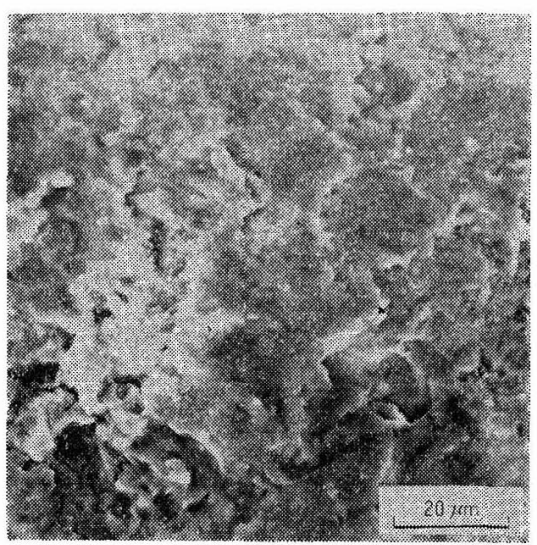

(d) 腐食生成物付着面 $\left(\sigma_{a}=9.8 \mathrm{MPa}\right)$ 
て括り， $S-t$ 曲線が 2 本の異なった曲線で構成されてい る。短寿命域の $S-t$ 曲線は機械的応力がき裂進展に直 接関与する通常の腐食疲労強度域, 長寿命域で再び下降 しはじめる部分の $S-t$ 曲線は, 腐食溶解によるき裂進展 が問題となる腐食進展域に該当する。このとき観察され る代表的な破面を図 195) と示す。図 19(a) は，比較的 短寿命の腐食疲労強度域で観察される粒界, 粒内混合面 であり，(b)，(c) はともに腐食溶解によりき裂が進展し たことを示す腐食進展域に属する破面である。図 19 (d) は破面上に固着した腐食生成物である。

こうして観察される破面性状を, 粒界割れ面, 粒内割 れ面, 腐食進展面, 腐食生成物付着面, 衝突面, 最終デ ィンプル破壊面に分類し, 種々の公称応力値 $\left(\sigma_{0}\right)$, 裂深 さの破面を区分した結果を図 $20^{35)}$ 亿示す。 $\sigma_{0}>50 \mathrm{MPa}$ では粒界, 粒内混合面が, $\sigma_{0}<50 \mathrm{MPa}$ では腐食溶解面 が破面の大半を占めること，き裂が深くなると腐食生成 物が固着した面が多くなることが明らかであり, 図 18 の $S-N$ 曲線の変化とよく対応している。

図中 $t \cong 5 \times 10^{3} \mathrm{~h}$ で破断した $\sigma_{0}=9.8 \mathrm{MPa}$ 下の結果 飞ついて, その平均の深さ方向へのき裂進展速度を概算 すると $d l / d N \cong 10^{-9} \mathrm{~mm} /$ cycle であり, 平均の応力拡大 係数幅は 1 2 $\mathrm{MPa} \sqrt{\mathrm{m}}$ と極めて低い。腐食溶解によ るき裂進展が問題となる長寿命域では，腐食疲労による $d l / d n$ が完全に零となる $K$ の下限界値 $\Delta K_{\mathrm{CF}}$ は存在しな いようである。これと関連して Speidel は $\mathrm{Al}$ 合金, $\mathrm{Mg}$

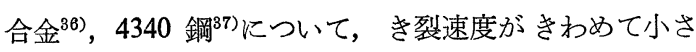
くなる $\Delta K_{\mathrm{CF}}$ を

$$
\Delta K_{\mathrm{CF}}=(2.7 \pm 0.3) 10^{-5} E \sqrt{\mathrm{m}}
$$

で近似できるとしている。これに鋼の弾性係数 $E=2.06$ $\times 10^{5} \mathrm{MPa}$ を代入すると, $\Delta K_{\mathrm{CF}}=4.9 \sim 6.2 \mathrm{MPa} \sqrt{\mathrm{m}}$ と なるが，この值は上述の公称応力 $\sigma_{0}=10 \mathrm{MPa}$ で破断し た試験片に負荷された平均の $K$ 值よりかなり大きく，

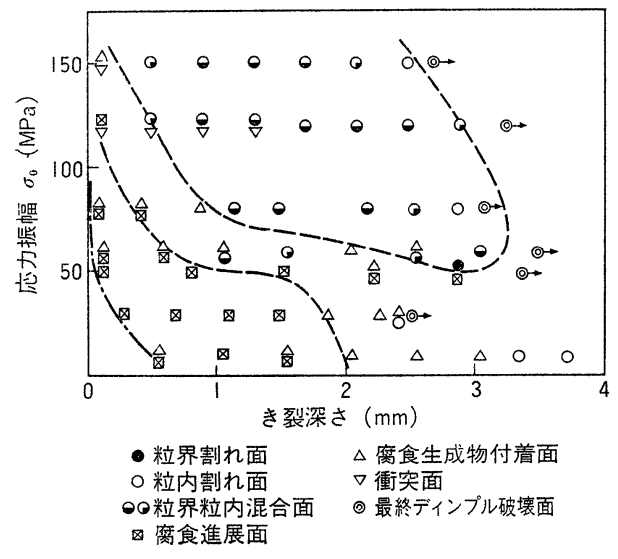

図 20 破面の変化 $^{35)}$
$\Delta K_{\mathrm{CF}}$ の存在には疑問がある。

機械, 構造物は, 全天候下や乾湿繰返しなどの環境变 動下で稼動することも多いので, 腐食疲労強度に及ぼす 環境変動の効果が問題になる。図 18 亿, $1 \% \mathrm{NaCl}$ 湿食 (30 min)一大気 $(60 \mathrm{~min})$ の交互浸漬による試験結果を合 わせて示すように，空中耐久限度近傍の高応力域を除く と, 交互浸漬下の寿命は常に連続湿食下の寿命より長 い。これは，交互浸漬下においては，乾湿サイクルによ り密着性の良いさび層が形成されることによるとされて いる。

\section{8. 電気防食効果とその限界}

電流規制下でカソード防食を注どこして炭素鋼の疲労 試験を行った結果ををとめると，その効果は通電電流量 によって定まり，十分な電流密度のもとでは腐食疲労強 度は空中強度とほ涪等しくなる。図 $21^{38)}$ に $0.1 \mathrm{MKCl}$ 中の結果を示すように, $600 \mu \mathrm{A}$ 程度のカソード電流に よってほ淁中耐久限度と等しい腐食疲労強度が得られ ている。応力をパラメータにとって寿命を示すと, 図 ${ }^{228)}$ に示すように，応力が大きくなるほど腐食疲労の防

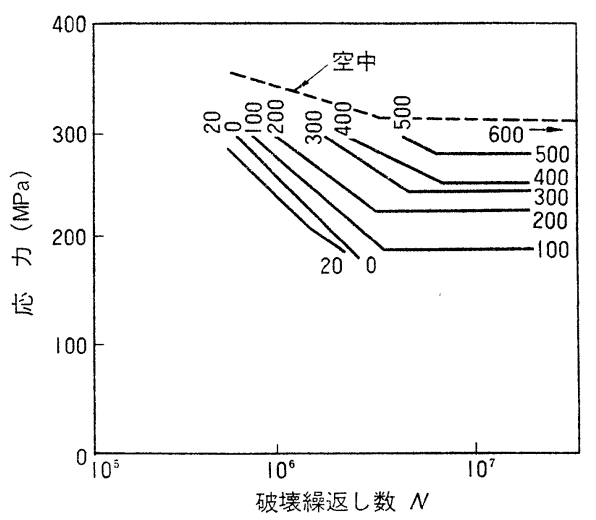

図 21 腐食瘦労強度に及ぼすカソード電流密度の 影響 ${ }^{38)}$ (軟鋼, $0.1 \mathrm{M} \mathrm{KCl}$ 中, 図中の数字は カソード電流 $\mu \mathrm{A}$ を示す)

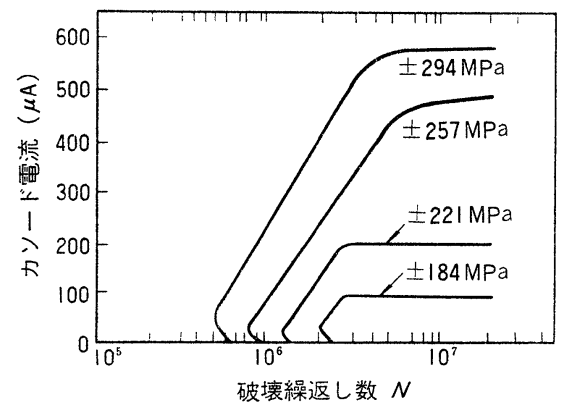

図 22 腐食疲労寿命と電流密度の関係 ${ }^{38}$ (軟鋼, $0.1 \mathrm{M} \mathrm{KCl}$ 中) 


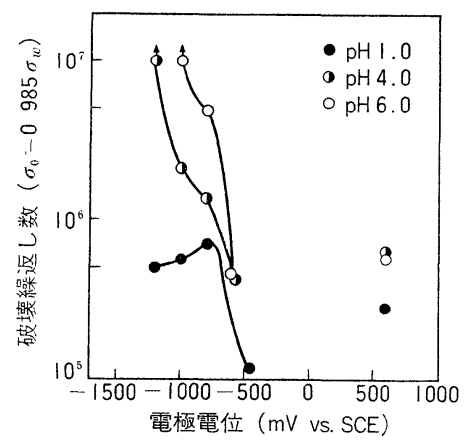

図 23 種々の設定電位の下での腐食疲労寿命 ${ }^{41)}$ (S35C, $f=30 \mathrm{~Hz}$ )

止に必要なカソード電流密度が増加する。

しかし，N/10 HCl 溶液中の軟鋼 ${ }^{38)}, 5 \% \mathrm{H}_{2} \mathrm{SO}_{4}$ 中の

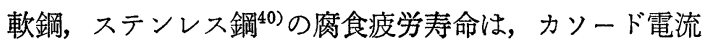
によって若干延長されはするが，完全に腐食疲労を抑制 することが不可能であることが報告されて扔り, 強酸溶 液中の腐食疲労にはカソード防食も不充分のようであ る。

從来はこのような電流規制下でのデータが多かった が，金属の腐食は電位-pH 線図からもわかるように電位 によって定まるから，電位規制によるほうが，正確かつ 経済的な防食が可能である。種々の $\mathrm{pH}$ 值の緩衝液中で 定電位条件下で腐食疲労試験 (S 35 C) を行ったときの破 壊寿命と設定電位の関係を図 2341) に示す。この場合も $\mathrm{pH} 1$ ではカソード防食は完全ではないが， $\mathrm{pH}$ 值の上 昇とともにカソード防食は容易となり， pH 4 では $-1200 \mathrm{mV}$ (vs. SCE), pH 6 では -1000 mV (vs. SCE) で完全防食が可能となるが，いずれも静腐食下のカソー ド防食電位 $-780 \mathrm{mV}$ (vs. SCE) より低い。 $\mathrm{pH} 3$ $\left(\mathrm{Na}_{2} \mathrm{SO}_{4}+\mathrm{H}_{2} \mathrm{SO}_{4}\right)$ 中の $0.09 \% \mathrm{C}$ 炭素鋼においても, $-840 \mathrm{mV}$ (vs. SCE) ではかなりの腐食疲労被害を受け るが，-1240 mV (vs. SCE) で腐食疲労強度が空中強度 とほぼ等しくなっている42)。

このよらに腐食疲労において静的カソード防食電位で は十分に防食できない理由は次のように考えられる ${ }^{41)}$ 。 鋼の腐食疲労に护る腐食速度の堌加は, 主として繰返 し応力による鉄電極の平衡電位の著しい低下（金属活量 の増加）に基づいている ${ }^{43)}$ 。鉄電極の平衡電位の低下は 電位-pH 線図に拈ける腐食域と不活性域の境界電位を 負方向へ移動させるので，負方向への腐食域が応力繰返 しとともに拡大する。そのために，始めカソード防食が 完全であっても，ある繰返し数以降完全に防食できなく なる。これは定電位下の腐食疲労に伴ら腐食溶解量をみ ることによっても理解される。図 2441) $206 \mathrm{MN} / \mathrm{m}^{2}$ に打ける種々の設定電位下の溶解量変化を

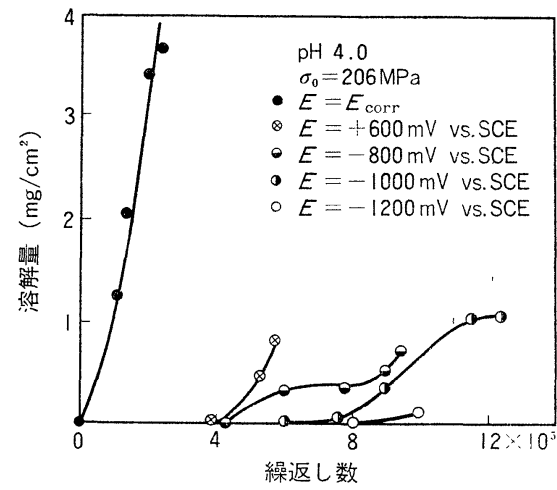

図 24 応力繰返しに伴う Fe 溶解 $^{41)}$

光電比色法により検出したものである。 $E=E_{\mathrm{corr}}$ ，すな わち自然腐食下では，初期から鉄溶解が増加する。カソ 一ド防食下では，この鉄溶解は初期は防がれているが, ある繰返し数より溶解が始まり，この鉄溶解が始まるま での潜伏期は設定電位が賲になるほど長いことがわか る。この潜伏期の長さは平均応力によって变化し, 平均 応力が引張りから民縮になるにしたがい長くなる44。同 様なことは腐食摩耗においてもみられ らず動的な応力を受ける部材にカソード防食を施す際に 注意を要することである。

このように, じん性材の腐食疲労に拈いては, カソー ド防食は極めて有効であり，静腐食下のカソード防食電 位より負に電位を設定することにより，平滑材の腐食疲 労強度を空中耐久限度と等しくすることができる。この ように，き裂発生を抑制するためのカソード防食はきわ めて有効であるが，き裂材に対するカソード防食の有用 性については，別途検討が必要であろう。

一方，アノード防食は図 23 にもその結果を示したよ うに，溶液の $\mathrm{pH}$ 值によらずその効果はほとんど期待で さない41,42)。これは, 試験初期においては試験片表面に 良好な不働態膜が維持され，不働態保持電流 $\left(i_{p}\right)$ 〕小さ な值を保つが，腐食疲労被害の蓄積とともに不働熊被膜 がしだいに不完全となって $i_{p}$ が増加し，電流が激しく 振動して電位設定が不可能となるためである。

近年使用の機会がましている高強度材に対してはカソ 一ド電圧印加に伴い派生する水素脆化による害作用を考 慮する必要がある。高強度 4340 鋼切欠さ材の $1 \% \mathrm{NaCl}$ 中に拈ける種々のカソード電位下に护破壊寿命の変 化を図 $25^{19)}$ に示す。カソード電圧の印加によりき裂発 生が抑制されていったん疲労寿命が増加するが，通常の 炭素鋼に和将る完全カソード防食電位 (-1000 mV vs. SCE）まで電位を低下させると，水素脆化によりさ裂が 発生して, 寿命は逆に減少し腐食疲労に対する完全なカ ソード防食効果は期待できない。図 25 においてA材は 


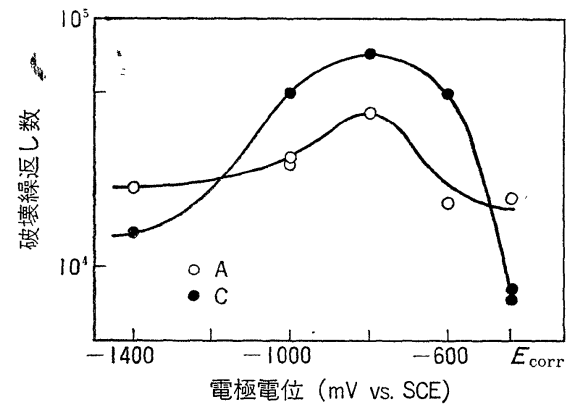

図 25 カソード電位一寿命線図 ${ }^{19)}(4340$ 鋼, $1 \%$ $\mathrm{NaCl}$ 中, $f=0.023 \mathrm{~Hz}$ )

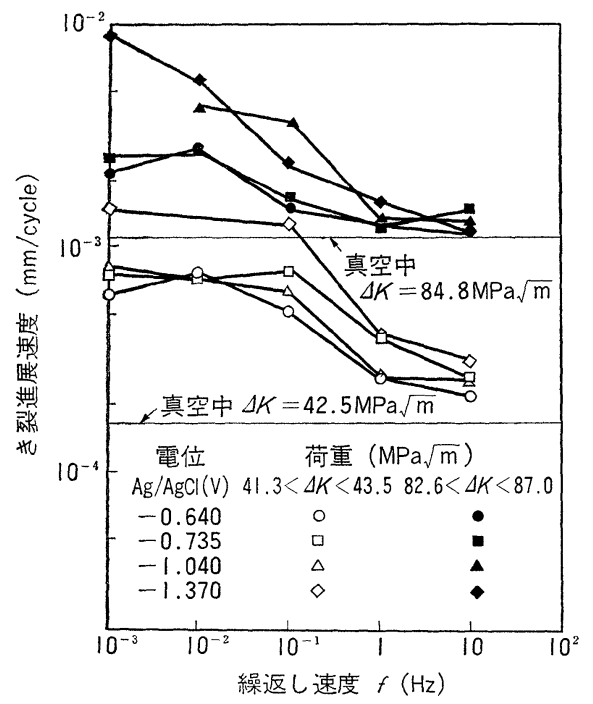

図 26 裂進展速度とカソード電位との関俰 ${ }^{46)}$ ( $\mathrm{HY}-80$ 鋼, $3.5 \% \mathrm{NaCl}$ 中)

$-600^{\circ} \mathrm{C}$ 筑戻し $\left(\sigma_{B}=1030 \mathrm{MN} / \mathrm{m}^{2}\right), \mathrm{C}$ 材は $-250^{\circ} \mathrm{C}$ 焼戻し $\left(\sigma_{B}=1820 \mathrm{MN} / \mathrm{m}^{2}\right)$ であるが，腐食疲労にては 抗張力の低い $-600^{\circ} \mathrm{C}$ 焼戻し材の注らがむしろ強度が 高いことに注意する必要がある。

カソード電位下で HY-80 鋼の $3.5 \%$ 食塩水中のき裂 速度が測定されて挌り， $\Delta K$ とさ裂速度の関係を図 2646) に示す。種々の繰返し速度のもとでカソード電位を印加 したもので，電位が卑になるほどき裂速度が增加し，繰 返し速度が低速になるほどその影響は著しい。このこと からこの材料の破壊に対しては水素脆化が支配的である としているが，とくに， $\Delta K$ が小さいとさカソード電位 の効果が約 $0.1 \mathrm{~Hz}$ で飽和するのに対し， $\Delta K$ が大きく て，き裂速度が速いときはその効果が $0.01 \mathrm{~Hz}$ でもまだ 飽和していないことは, き裂先端の水素の供給とき裂速 度の関係の一端を示しているように考えられる。

一方，高力 Al 合金に対してはカソード電位の効果は 低 $K$ 域でき裂進展速度が遅いとき，十分期待できるよう

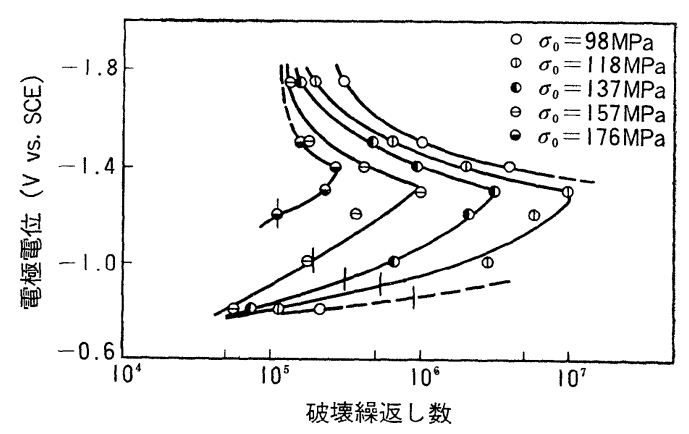

図 27 CF に対するカソード防食効果 ${ }^{48)}$ (ZK $41 \mathrm{Al}$ 合金, $1 \% \mathrm{NaCl}$ 中, $f=30 \mathrm{~Hz}$ )

である。 $\mathrm{Al}-\mathrm{Zn}-\mathrm{Mg}$ 合金の $3.5 \% \mathrm{NaCl}$ 中の疲労におい て，カソード防食効果はピーク時効処理（T 6) 材より も，過時効処理 $\left(177^{\circ} \mathrm{C}, 24 \mathrm{~h}\right)$ 材でより有効であり，ア ノード電圧をか外ると破面は脆性ストライェーションと なるが，カソード電圧をか外ると延性ストライエーショ ンとなり，十分低いカンード電位 $-1400 \mathrm{mV}$ (vs. SCE) 下では乾燥空気中の值にまでき裂速度を低下させう $3^{47)}$ 。

しかし, 同様の $\mathrm{Al}-\mathrm{Zn}-\mathrm{Mg}$ 合金平滑材のカソード防 食下の寿命変化を図 2748) に示すように，カソード防食 下では寿命が大幅に増加し， $E=-1300 \sim 1400 \mathrm{mV}$ (vs. SCE) で最大のカソード防食効果が得られるが，-1400 $\mathrm{mV}$ (vs. SCE) より負の過剩防食域では逆に寿命が短か くなる。 $-1400 \mathrm{mV}$ より負の電位下で, 過剩 $\mathrm{H}^{+}$によ る水素脆化の被害が現われたもので，吸蔵された水素が き裂発生を促進するとともに，E=-1300〜 - $1400 \mathrm{mV}$ (vs. SCE) 付近でいったん延性化したストライエーショ ンを再び脆化型にして，き裂速度を增加したことによ る。一般に面心立方構造を有する Al 合金は水素脆化を 起こしにくいとされているが，過剩カソード電流下に和 けるような水素吸蔵が強く促進される条件下では, $\mathrm{Al}$ 合 金に礼いてもき裂の発生と進展に対する水素脆化の害作 用を無視できない。また, 高平均応力下でもカソード防 食効果は注とんど期待できず，これはへき開破壊にカン ード電圧がきかないことによるとした報告48) ああり，高 力 $\mathrm{Al}$ 合金に対するカソード防食の適用には十分なる配 慮を必要とする。

\section{9. あとがき}

疲労に及ぼす環境の影響に関する最近の諸問題につい て展望した。高強度材料の疲労き裂進展に対する環境の 影響，とくに，SCC 共存の影響が注目されているが， 一般にき裂速度の大きい場合の実験結果が多く, き裂速 
度の遅い実用部材の設計データとして，これを外插する ことは，とくに腐食疲労において問題が多いようである。 また，一般によく用いられるじん性材料についても，低 繰返し速度域に扣けるき裂発生を含む材料の劣化や，設 計データになりらる長時間強度が必要とされて括り, 根 気の必要な研究がまたれている。

扮わりに本稿をまとめるにあたって，種々貴重な意見 を賜った京都大学遠藤吉郎教授に対し深く感謝するしだ いである。

\section{文献}

1) M. J. Hordon \& M. A. Wright: Trans. Met. Soc. AIME, 242, 2011 (1968).

2）遠藤吉郎，駒井謙治郎：材料， 26, 143 (1977).

3）遠藤吉郎, 駒井謙治郎: 古川修, 機械学会論 文 集, 32, 1800 (1966).

4) A. Hartman: Intern. J. of Fract. Mech., 1, 167 (1965).

5) F. J. Bradshaw \& C. Wheeler: Intern. J. of Fract. Mech., 5, 255 (1969).

6) J. S. Enochs \& O.F. Devereux: Metallurg. Trans., 6A, 391 (1975).

7) J. A. Dunsby \& W. Wiebe: Mat. Res. Stands., 9, 15 (1969).

8) Che-Yu Li, P. M. Talda and R. P. Wei: Intern. J. Fract. Mech., 3, 29 (1967).

9) J. Kramer: Z. Phys., 125, 739 (1949).

10) M. Hempel, A. Kochendörcher und A. Tietze: Archiv. f. Eisenhüttenw., 35, 465 (1964).

11）駒井謙治郎：金属学会誌，40, 964 (1976).

12) L. Grunberg: Proc. Phys. Soc. Lond., Ser. B, 66, 153 (1953).

13) J. C. Grosskreutz: J. Appl. Phys., 33, 2653 (1962).

14) J. A. Bennet: Fatigue of Aircraft Structures, Edited by W. Barrois and E. L. Ripley, Pergamon Press, 1 (1963).

15) J. Lohff: Z. Phys., 146, 436 (1956).

16）佐藤教男：金属学会会報, 7, 313 (1968).

17) T. Broom \& A. Nicholson: J. Inst. Metals, 89, 183 (1961).

18) J. A. Ramsey: Surface Science, 8, 313 (1967).

19）遠藤吉郎, 駒井謙治郎, 今城信雄：機械学会論 文集, 42, 2652 (1976).

20）遠藤吉郎，駒井謙治郎，大西一男：材料， 17, 160 (1968).

21）遠藤吉郎，駒井謙治郎，鈴木幸雄：機械学会論 交集, 40, 1262 (1974).

22) J. M. Barsom: Intern. J. of Fract. Mech., 7,
163 (1971).

23) T. W. Crooker \& E. A. Lange: J. of Basic Engng., Trans. ASME, 91, 570 (1969).

24) J. P. Gallagher, J. T. Ryder \& J. C. Hadley: Proc. Intern. Conf. on Mech. Behav. of Materials, Kyoto, 3, 328 (1972).

25) D. A. Meyn: Metallurgical Trans., 2, 853 (1971).

26）遠藤吉郎，駒井謙治郎：材料， 13, 536 (1964).

27）遠藤吉郎，駒井謙治郎：材料, 14, 827 (1965).

28) J. M. Barsom: Proc. Intern. Conf. on Cor. Fat., NACE-2, 424 (1972).

29) G. E. Nordmark, H. S. Hunter \& B. W. Lifka: ibid., 484.

30) R. J. Selines \& R. M. Pelloux: Metallurg, Trans., 3, 2525 (1972).

31）遠藤吉郎, 駒井謙治郎, 黒田知明：機械学会論 文集, 40, 3267 (1974).

32) G. A. Miller, S. J. Hudak and R. P. Wei: J. of Testing and Evaluation, 1, 524 (1973).

33）遠藤吉郎，駒井謙治郎，辻 宏和：機械学会論 文集，投稿中。

34) R. P. Wei \& J. D. Landes: Mat. Res. Stands., 9, 25 (1969).

35） 遠藤吉郎，駒井謙治郎，木下 定：材料， 25 , 894 (1976).

36) M. O. Speidel, M. J. Blackburn, T. R. Beck \& J. A. Feeney：文献 28) の 324.

37) M. O. Speidel: "Hydrogen in Metals", Intern. Conf. in Paris, 290 (1972).

38) U. R. Evans \& M. T. Simnad: Proc. Roy. Soc. London, A, 188, 372 (1947).

39) M. T. Simnad \& U. R. Evans: J. Iron Steel Inst., 156, 531 (1947).

40） 木島 茂：材料試験，11，596 (1962).

41）遠藤吉郎，駒井謙治郎，岡 清治：材料, 19, 36 (1970).

42) M. Hempel, A. Kochendörcher \& P. Flitsche: Archiv. f. Eisenhüttenw., 37, 399 (1966).

43）遠藤吉郎，駒井謙治郎：材料， 17, 40 (1968).

44）遠藤吉郎，駒井謙治郎，高林重信：材料, 21, 29 (1972).

45）遠藤吉郎，駒井謙治郎，藤田大東：機械学会論 文集, 36, 1961 (1970).

46) J. P. Gallagher: J. of Materials, 6, 941 (1971).

47) R. E. Stoltz \& R. M. Pelloux: Metallurg. Trans., 3, 2433 (1972).

48）遠藤吉郎, 駒井謙治郎, 渡瀬善教：材料, 24, 1140 (1975).

49) J.A. Whittaker: J. Inst. Metals, 91, 346(1963). 